\title{
Influence of a wastewater treatment plant on mercury contamination and sediment characteristics in Vidy Bay (Lake Geneva, Switzerland)
}

\author{
Elena Gascon Diez • Andrea Garcia Bravo • Natacha à Porta • \\ Matthieu Masson • Neil D. Graham • Serge Stoll • Yosef Akhtman • \\ David Amouroux · Jean-Luc Loizeau
}

Received: 10 April 2013/Accepted: 23 October 2013

(C) Springer Basel 2013

\begin{abstract}
Previous direct observations of the sediment surface in Vidy Bay, Lake Geneva (Switzerland), revealed a range of sediment characteristics in terms of colour, texture and morphology. Dives with the MIR submersibles during the éLEMO project permitted the exploration of a large portion of Vidy Bay. It is the most contaminated part of Lake Geneva, due to inputs of treated and untreated waters from a large wastewater treatment plant (WWTP). To evaluate the influence of WWTP effluent on mercury contamination and sediment characteristics, 14 sediment cores were retrieved in the vicinity of the wastewater treatment plant effluent. Total mercury concentrations in sediments ranged between 0.32 and $10.1 \mathrm{mg} / \mathrm{kg}$. Inorganic mercury and monomethylmercury concentrations in overlying and pore waters were also measured. The total partition coefficients of mercury $\left(\log K_{\mathrm{d}}\right)$ ranged from 3.6 to 5.8. The monomethylmercury concentration in pore waters of surface sediments was a large proportion of the total mercury concentration (44 $\pm 25 \%)$. A Spearman test showed a negative correlation between the
\end{abstract}

This article is part of the special issue "éLEMO - investigations using MIR submersibles in Lake Geneva".

E. Gascon Diez $(\bowtie) \cdot$ N. à Porta · N. D. Graham · S. Stoll ·

J.-L. Loizeau

Earth and Environmental Sciences Section, Faculty of Sciences, Institut F.-A. Forel, Route de Suisse 10, 1290 Versoix,

Switzerland

e-mail: Elena.Gascon@unige.ch

E. Gascon Diez · N. à Porta · N. D. Graham · S. Stoll ·

J.-L. Loizeau

Institute for Environmental Sciences, University of Geneva,

1211 Geneva, Switzerland

A. G. Bravo

Limnology Department, Evolutionary Biology Centre, EBC,

Norbyvägen 18D, 75236 Uppsala, Sweden distance to the wastewater treatment plant outlet and the concentrations of total mercury in sediments and pore waters. Visual observations from the submersible allowed recognizing six different types of sediment. The areal distribution of these different sediment types clearly showed the influence of the wastewater treatment plant outlet on the sediment surface patterns. However, no relationship with mercury concentrations could be established.

Keywords Methylmercury · Lake sediment . Wastewater treatment plant · Pore water

\section{Introduction}

Mercury ( $\mathrm{Hg}$ ) is a global pollutant and its toxicity depends on the distribution of its various forms (Langer et al. 2001). Monomethylmercury (MMHg) is one of the most hazardous $\mathrm{Hg}$ species since it bioaccumulates in organisms and biomagnifies along the food chain (Watras and Bloom 1992; Mason et al. 1995; Cossa et al. 2012) and it is a neurotoxin to humans and wildlife (WHO/IPCS 1990; Clarkson 1993; Harada 1995; Scheulhammer et al. 2007; Blank et al. 2013).

M. Masson

Department of Inorganic and Analytical Chemistry,

Faculty of Sciences, University of Geneva, Sciences II,

30 Quai E-Ansermet, 1211 Geneva, Switzerland

Y. Akhtman

Ecole Polytechnique Fédérale de Lausanne EPFL ENAC IIE

TOPO, Station 18, 1015 Lausanne, Switzerland

D. Amouroux

Laboratoire de Chimie Analytique Bio-Inorganique et

Environnement, IPREM UMR 5254 CNRS, Université de Pau et des Pays de l'Adour, Hélioparc, 64053 Pau, France 
The main sources of $\mathrm{Hg}$ in lakes are watershed runoff and atmospheric deposits (Fitzgerald et al. 1991). $\mathrm{Hg}$ in superficial waters can be either dissolved or adsorbed onto suspended particles and organic matter (OM) in the water column. $\mathrm{Hg}$ is exchanged between aquatic compartments through various physicochemical processes such as diffusion, sedimentation, erosion, dissolution and bacterial transformation. Therefore, $\mathrm{Hg}$ in the solid phase, having reached the sediments, can be buried, resuspended, released or even methylated, making sediments a sink and a source of $\mathrm{Hg}$ (Blasco et al. 2000; Bale 2000). Methylation occurs primarily, but not exclusively, in anoxic waters and sediments (DeLaune et al. 2004). It is carried out by some species of bacteria belonging to the groups of sulphate(SRB) and iron-reducing bacteria (IRB) (Compeau and Bartha 1985; Gilmour and Henry 1991; Gilmour et al. 1992; Pak and Bartha 1998; Kerin et al. 2006; Fleming et al. 2006; Hamelin et al. 2011; Parks et al. 2013). Geochemical parameters such as $\mathrm{Eh}, \mathrm{pH}$, nutrient availability, and temperature as well as the concentration of inorganic and organic complexing agents will influence the fate of the particulate $\mathrm{Hg}$ in aquatic systems (Ullrich et al. 2001).

Lake Geneva (Switzerland-France) is the largest freshwater lake in Western Europe with a total volume of $89 \mathrm{~km}^{3}$. Since the implementation of a Wastewater treatment plant (WWTP) in Lausanne in 1964, its effluents have affected the sediments in Vidy Bay. Among other pollutants, high concentrations of OM, total mercury ( $\mathrm{THg}$ ), bacteria and trace metals have been recorded (Loizeau et al. 2004; Pardos et al. 2004; Pote et al. 2008). Dephosphorization treatment, based on the addition of iron chloride in the WWTP, induced the release of iron into the bay. $\mathrm{Hg}^{2+}$ and $\mathrm{MMHg}$ have a high tendency to form complexes, in particular with soft ligands such as sulphur and iron (Ullrich et al. 2001). In anoxic conditions, oxyhydroxides dissolve and release any associated $\mathrm{Hg}$. The dissolution of iron colloids, or the presence of electronacceptors for metal-reducing bacteria, may stimulate the release of $\mathrm{Hg}$ from the solid phase and, consequently, enhance $\mathrm{Hg}$ methylation (Fleming et al. 2006).

As anthropogenic $\mathrm{Hg}$ in aquatic environments is of major concern, we focus on a specific area of approximately $1 \mathrm{~km}^{2}$ in Vidy Bay, which has already been proven to be the most contaminated area of the lake (e.g. Pote et al. 2008). Previous direct observations in the Bay using a submarine pointed out the presence of heterogeneous surface sediments, characterized by marked differences in sediment colour and texture; particularly, white, black, and greenish or brownish surface sediment had been observed (J.-L. Loizeau, personal communication). Some of the observed physical differences are related to the presence of a bacterial mat and likely to redox conditions; i.e., white coatings are probably due to the presence of Beggiatoa, a genus of white, filamentous proteobacteria (Sauvain et al. 2013 , this issue). The aim of this research is to determine if, besides the influence of the distance from the $\mathrm{Hg}$ source, there is any large-scale influence of the various sediment types (reflecting both sedimentological and biogeochemical processes) on $\mathrm{THg}$ concentrations in sediments, and $\mathrm{THg}$ and $\mathrm{MMHg}$ contents in pore waters.

\section{Methods}

Direct sediment observation

In the frame of the éLEMO project (Wüest et al. 2013, this issue), six dives (June 20 and 21; July 19, 21, and 22; and August 16, 2011) were performed in Vidy Bay using the MIR scientific sumersibles. These dives, covering a total length of $16.6 \mathrm{~km}$ (Fig. 1), were performed close to the lake sediments in order to directly observe sediment structures, textures and colours, and to collect sediment cores. Video recordings were made to document sediment surface characteristics. These videos, in addition to dive logs, served as a basis to establish a detailed map of the sediment structures present in the Bay. Correspondence of video with positioning was based on the time given by GPS. Submarine trajectories and core positions (Table 1) were calculated based on the GPS position of the floating platform, triangulation of the submersibles, and interpolation of missing data (Akhtman et al. 2012). Additional images were also obtained using a mini video camera attached to a corer deployed from the La Licorne research vessel.

Six types of sediment surfaces based on colour, texture, and structure (Figs. 1, 2) were distinguished. They are described following their occurrence from the deep basin towards the lakeshore and WWTP outlet as following:

Type 1 is characterized by enigmatic, yet well developed cushion and trench structures (Fig. 2a). Cushions are generaly $40-60 \mathrm{~cm}$ in diameter, surrounded by 10-20 cm wide depressions. The vertical amplitude of the structures is about $10-20 \mathrm{~cm}$. The sediment surface was beige and composed by clayey silts. It was observed in the deepest part of the bay, and covers a large surface area extending beyond the present survey. These structures have been previously described (Vernet 1966; Sturm et al. 1984; Dominik et al. 1992) and no core was retreived in this sediment type.

Type 2 corresponds to a fine-grained, flat, beige sediment surface, crossed by long shallow trenches (Fig. 2b). It was observed at the rim of the cushiontrench structures. It covers small surface areas in the Bay (Fig. 1). Core \#11 was retreived from this sediment type; 


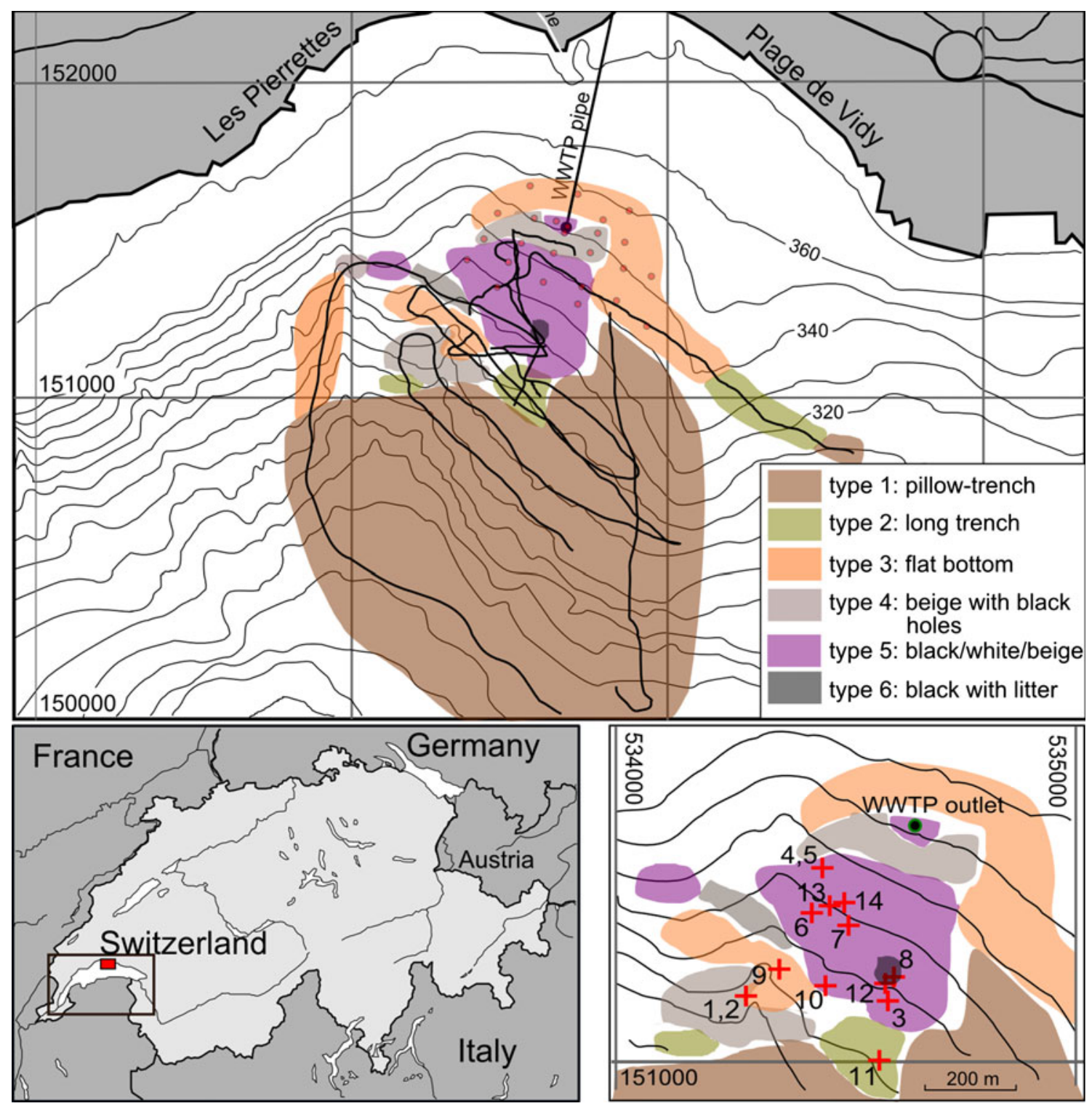

Fig. 1 Map of Vidy Bay and sediment type distribution. Bold lines represent routes of the submarine; small red circles are punctual observations with a submerged camera. Insets: left; situation of Lake
Geneva on the Switzerland-France border. The red square indicates the location of Vidy Bay; right, close view of the sediment core locations (red crosses)

resembling a camouflage pattern. Sediment colours vary between beige, black, and white (Fig. 2e). Individual surface colour areas range from square decimetres to metres. This sediment type was essentially observed at the outlet of the WWTP, and covers an area of approximately $0.25 \mathrm{~km}^{2}$. Most cores (\#3 to \#7, \#10, \#13, \#14) were collected in this sediment type in different colour zones.

Type 6 corresponds to a very small area in the Bay, a few hundreds of $\mathrm{m}^{2}$. It is distinct because the sediments were almost entirely greyish-brown to black and covered by litter (including q-tips, cigarette butts, and sanitary towels, Fig. 2f). This type was observed $300 \mathrm{~m}$
Type 5 is charaterized by a heterogeneous assemblage of sediment colour on relatively flat sediment surface, 
Table 1 Sediment core locations and corresponding sediment type

\begin{tabular}{|c|c|c|c|c|c|c|c|}
\hline \multirow{2}{*}{$\begin{array}{l}\text { Core } \\
\text { Number }\end{array}$} & \multicolumn{2}{|c|}{ WGS 84 coordinates } & \multicolumn{2}{|c|}{ SWISS coordinates } & \multirow{2}{*}{$\begin{array}{l}\text { Distance to } \\
\text { WWTP outlet } \\
\text { (m) }\end{array}$} & \multirow{2}{*}{$\begin{array}{l}\text { Depth } \\
\text { (m) }\end{array}$} & \multirow{2}{*}{$\begin{array}{l}\text { Sediment } \\
\text { Type }\end{array}$} \\
\hline & $\begin{array}{l}\text { Latitude } \\
\text { (Deg decim) }\end{array}$ & $\begin{array}{l}\text { Longitude } \\
\text { (Deg decim) }\end{array}$ & $\begin{array}{l}N \\
(\mathrm{~m})\end{array}$ & $\begin{array}{l}E \\
(\mathrm{~m})\end{array}$ & & & \\
\hline 1 & 46.50856 & 6.58275 & 151,165 & 534,309 & 526 & 48 & 3 \\
\hline 2 & 46.50853 & 6.58274 & 151,161 & 534,308 & 529 & 49 & 3 \\
\hline 3 & 46.50842 & 6.58674 & 151,146 & 534,615 & 403 & 51 & 5 \\
\hline 4 & 46.51111 & 6.58481 & 151,447 & 534,470 & 226 & 45 & 5 \\
\hline 5 & 46.51114 & 6.58479 & 151,450 & 534,468 & 226 & 45 & 5 \\
\hline 6 & 46.51024 & 6.58528 & 151,349 & 534,505 & 258 & 53 & 5 \\
\hline 7 & 46.51002 & 6.58563 & 151,325 & 534,532 & 262 & 52 & 5 \\
\hline 8 & 46.50888 & 6.58689 & 151,197 & 534,627 & 351 & 54 & 6 \\
\hline 9 & 46.50905 & 6.58367 & 151,219 & 534,380 & 438 & 69 & 3 \\
\hline 10 & 46.50873 & 6.58497 & 151,183 & 534,479 & 411 & 43 & 5 \\
\hline 11 & 46.50710 & 6.58653 & 151,004 & 534,598 & 543 & 68 & 2 \\
\hline 12 & 46.50876 & 6.58670 & 151,184 & 534,612 & 366 & 60 & 6 \\
\hline 13 & 46.51040 & 6.58508 & 151,368 & 534,490 & 255 & 50 & 5 \\
\hline 14 & 46.51047 & 6.58548 & 151,375 & 534,521 & 228 & 50 & 5 \\
\hline WWTP outlet & 46.51572 & 6.58822 & 151,956 & 534,738 & 0 & 35 & 5 \\
\hline
\end{tabular}

downslope of the WWTP effluent within the type 5 sediment area. Cores \#8 and \#12 were collected in this sediment type.

Core sampling and sediment processing

A total of 14 cores, using a specially designed push corer (Girardclos et al. 2012), were retrieved in the different zones of the Bay defined by visual observations. Sediment cores were transported to a nearby laboratory where they were placed in a glove-tent under an $\mathrm{N}_{2}$-atmosphere. The overlying water was extracted with syringes and a subsample was stored in clean bottles (see procedure below). The remainder was filtered through $0.45 \mu \mathrm{m}$ Sterivex syringe filters and stored in $250 \mathrm{ml}$ Teflon bottles at $4{ }^{\circ} \mathrm{C}$. Both filtered and unfiltered water samples were acidified with suprapur $\mathrm{HCl}(1 \% \mathrm{v} / \mathrm{v})$. Sediments were extruded and sliced at $0-1.5 \mathrm{~cm}, 1.5-3 \mathrm{~cm}$, and $3-6 \mathrm{~cm}$ intervals. Each sediment layer was transferred to a Teflon centrifugation tube and centrifuged at 3,500 rpm for $40 \mathrm{~min}$ to extract the pore water. The centrifuge tubes were placed back into the glove-tent under $\mathrm{N}_{2}$-atmosphere where the supernant water was filtered with $0.45 \mu \mathrm{m}$ Sterivex syringe filters, and stored in $30 \mathrm{ml}$ Teflon flasks inside two polyethylene bags. The cleaning procedure for the Teflon bottles and vessels used to store water and analyse mercury species was carried-out in series of three baths: (1) a soap Extran ${ }^{\circledR}$ MA 03 bath for $1 \mathrm{~h}$ under sonification and then rinsed with MilliQ water; (2) 2-h sonification in a $10 \%$ nitric acid bath, conducted a second time after changing the acid and rinsing with MilliQ water; and (3) 2-h sonification in a $10 \% \mathrm{HCl}$ bath and MilliQ water rinse.

Sedimentological and chemical analyses

Sediment grain-size distribution was determined on wet sediments using a laser diffraction Coulter LS-100 analyser, following the procedure described by Loizeau et al. (1994). Sediments were freeze-dried in a CHRIST BETA 1-8 $\mathrm{K}$ freeze-drying unit $\left(-54{ }^{\circ} \mathrm{C}, 6 \mathrm{~Pa}\right)$ for a minimum of $48 \mathrm{~h}$. The organic matter content in sediments $\left(\mathrm{OM}_{\text {sed }}\right)$ was measured by Loss On Ignition (LOI); samples were heated to $550{ }^{\circ} \mathrm{C}$ for $1 \mathrm{~h}$ in a muffle furnace (Nabertherm-LE14/ 11). Sulphate concentration in pore water was measured by Ionic Chromatography (Dionex ICS-3000) with a Ion$\mathrm{Pac}^{\circledR} \mathrm{AS} 19$ (4.250 mm) column. Iron concentration in pore water was measured by FG-AAS (Varian, AA240FS). The accuracy was within $8 \%$ of certified values of the reference material (SLRS-4) and the analytical error was $<5 \%$.

Total mercury in dry sediment $\left(\mathrm{THg}_{\text {sed }}\right)$ was analysed by Cold Vapor Atomic Absorption Spectrophotometry (CVAAS) using an automatic mercury analyser, Altec Model AMA 254 (Száková et al. 2004), following the procedure described by Roos-Barraclough et al. (2002) and Schafer et al. (2006). All analyses were run in triplicate. The detection limit and working range were 0.01 and 0.05-600 ng, respectively. Concentrations obtained for repeated analyses of the certified reference material never exceeded the specified range given for MESS-3 reference material (National Research Council Canada). 


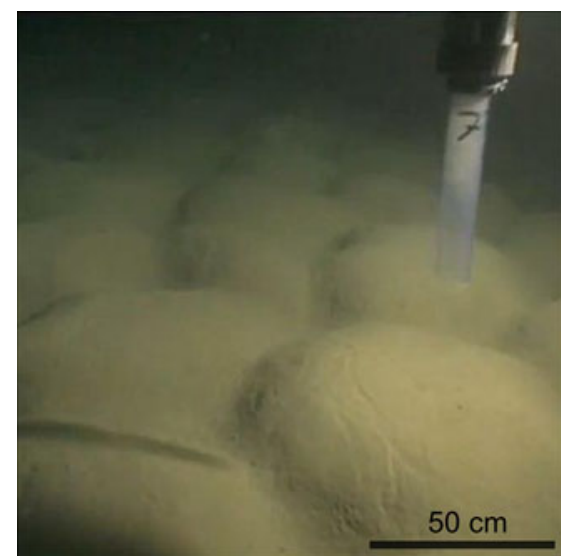

(a) sediment type 1

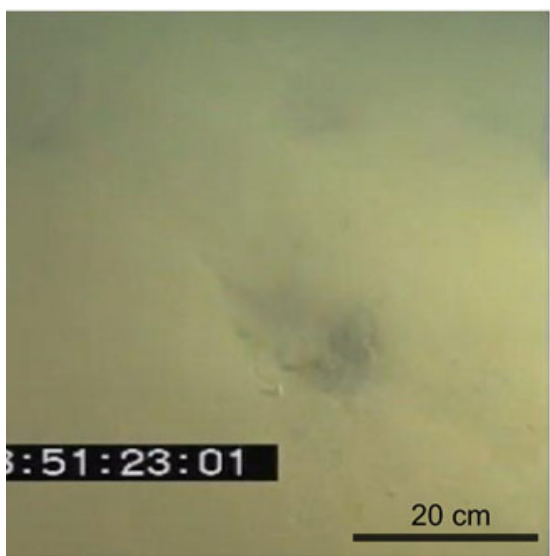

(d) sediment type 4

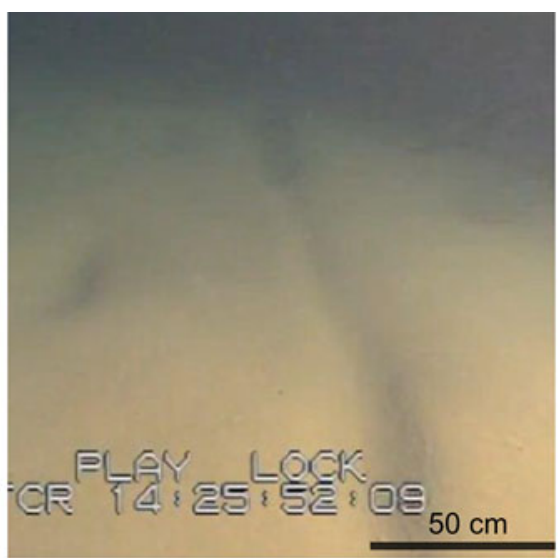

(b) sediment type 2

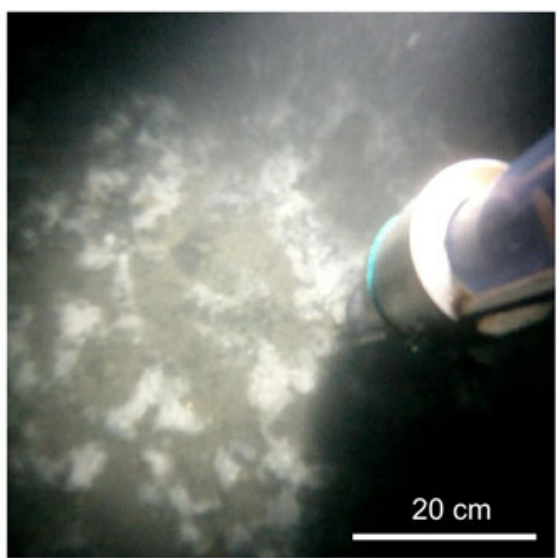

(e) sediment type 5

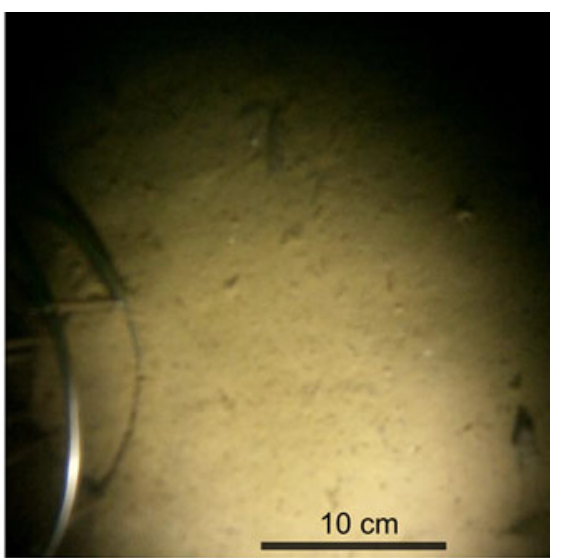

(c) sediment type 3

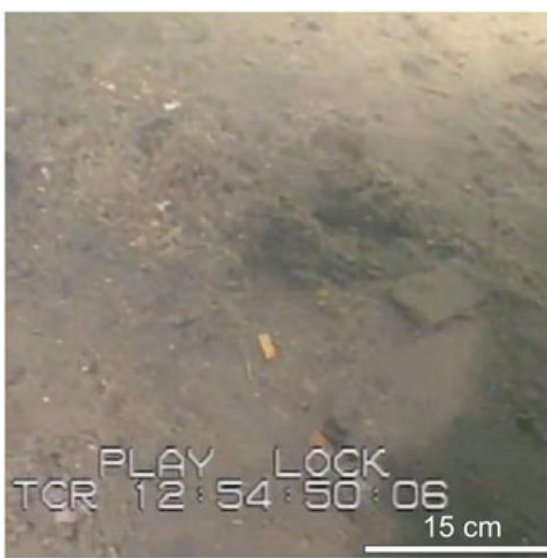

(f) sediment type 6
Fig. 2 Photos of the different types of sediments surfaces. Type 1trenches and cushions; Type 2-long trenches; Type 3-flat beige sediment; Type 4-flat beige surface with holes; Type 5-black/ whitelbeige sediment; Type 6 - flat with debris (cigarette butts, paper,

$\mathrm{MMHg}$ and $\mathrm{IHg}$ (inorganic mercury) in overlying and pore waters $\left(\mathrm{MMHg}_{\mathrm{OW}}, \mathrm{MMHg}_{\mathrm{PW}}\right.$ and $\mathrm{IHg}_{\mathrm{OW}}, \mathrm{IHg}_{\mathrm{PW}}$, respectively) were analysed by species-specific isotopic dilution and capillary gas chromatography (Focus GC, ThermoFinnigan) coupled to an ICP-MS (X7 II, ThermoElectron) to correct for species inter-conversion (Monperrus et al. 2005). Total mercury concentrations in overlying and pore waters $\left(\mathrm{THg}_{\mathrm{OW}}, \mathrm{THg}_{\mathrm{PW}}\right)$ were obtained by adding $\mathrm{MMHg}_{\mathrm{PW}}$ and $\mathrm{IHg}_{\mathrm{PW}}$ concentrations. $\mathrm{MMHg}$ concentrations in sediment were not measured because Bravo et al. (2011) had shown a positive correlation with THg concentration. Thus, the MMHg concentration in the sediments sampled would follow the same trends as exhibited by THg.

\section{Statistical analyses}

As data were not normally distributed, a Spearman test was used to evaluate correlations between the distance to the sanitary towels, etc.). Pictures were taken from the MIR submarines, with the exception of types 3 and 5, which were taken from a camera attached to sampling device

wastewater outlet and the $\mathrm{Hg}$ forms and $\mathrm{OM}$ concentrations. The Spearman rank correlation coefficient $r_{\mathrm{s}}$ was computed into a $p$ value to determine if the variables were significantly correlated (Siegel 1956). The level of significance was set to 0.05 . Statistical analyses were performed with R 2.14.1 software. As sediment types 2 and 3, as well as 5 and 6 , were solely discriminated by their morphology, cores retrieved in these sediment types were grouped as type 2-3 and 5-6 for the statistical analysis.

The distances between the WWTP outlet and the cores were significantly different between types $2-3$ and 5-6. Therefore, when the correlation between the distance to the outlet and the measured variable was statistically significant, it was not possible to separate the effects of distance to the WWTP outlet from the effect of sediment type. In turn, the Mann-Whitney-Wilcoxon test was used to assess the influence of sediment type on the measured variable when the correlation to distance was not significant. 


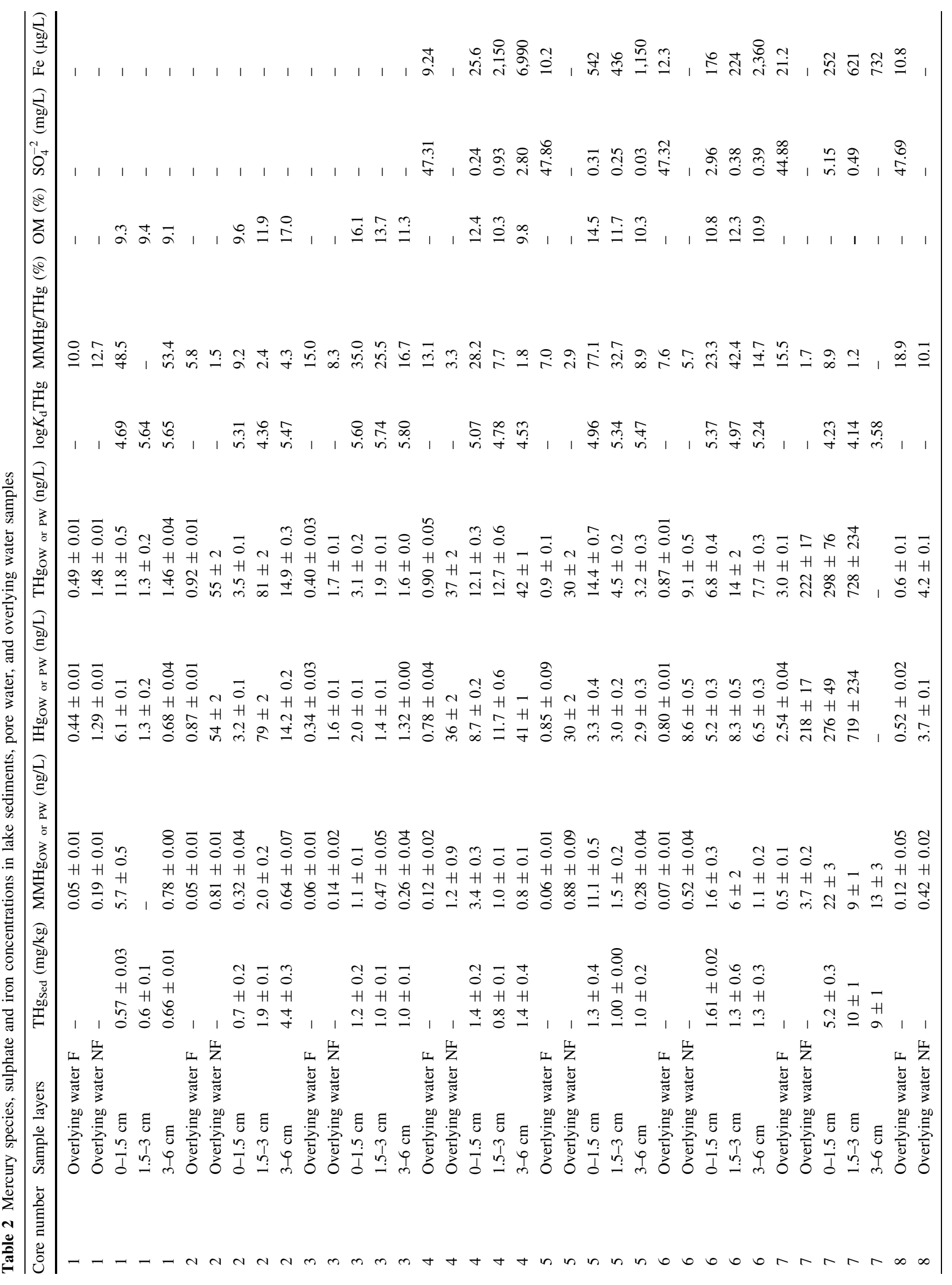




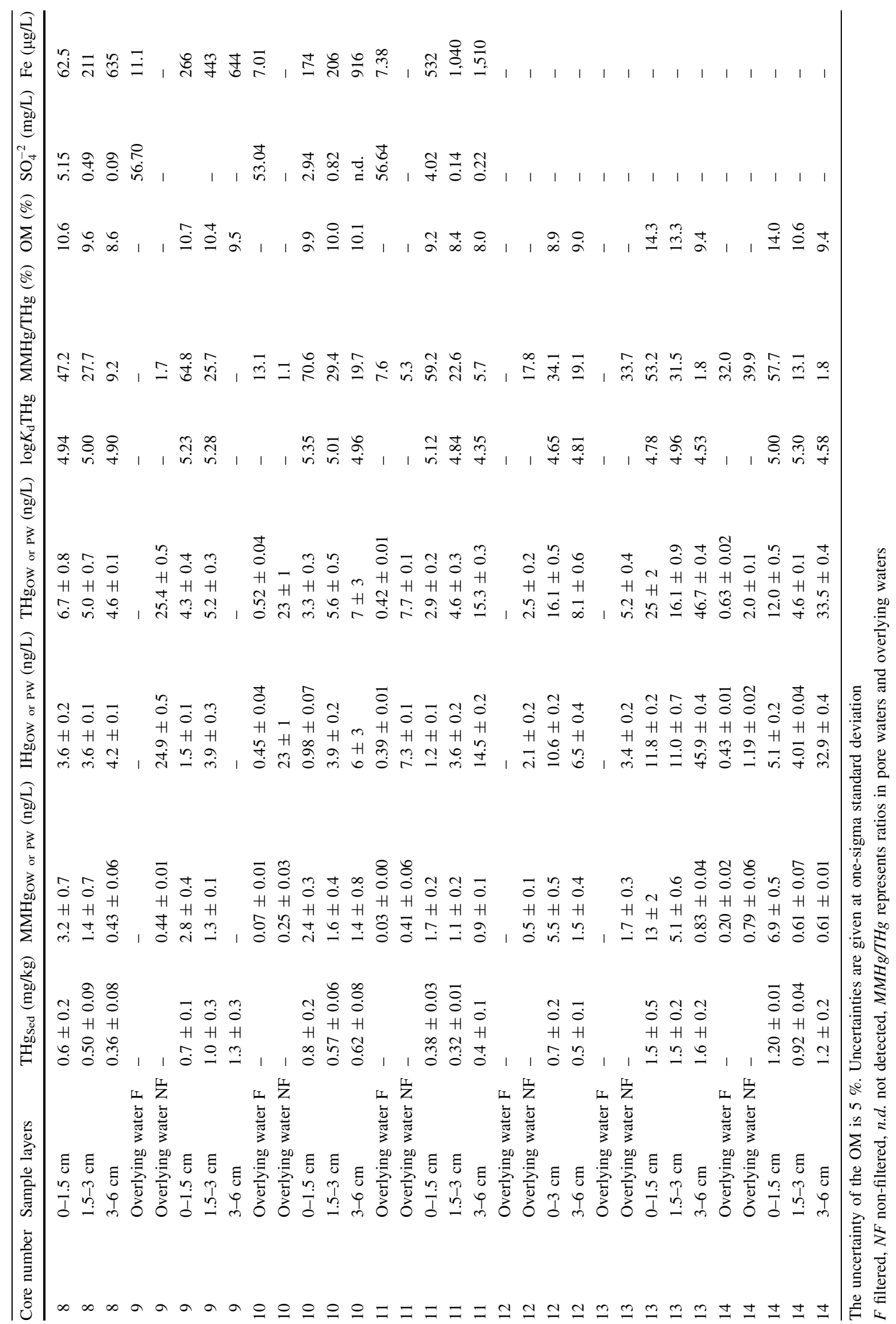




\section{Results and discussion}

Surface sediment analyses

The 14 cores were mainly collected on the downward slope from the WWTP outlet (Fig. 1, inset). Distances of coring sites to the WWTP outlet ranged from 226 to $543 \mathrm{~m}$ (Table 1). Surface sediments were sandy silt containing a relatively large proportion of organic matter (9-16\%) related to the WWTP effluent. The mean grain size was $68 \pm 22 \mu \mathrm{m}$.

The concentrations of sulphate $\left(\mathrm{SO}_{4}^{-2}\right)$ and dissolved iron (Fe) in pore and overlying waters (Table 2) gave indications on the redox conditions of the water samples. Concentrations of $\mathrm{SO}_{4}^{-2}$ in overlying water varied between 45 and $56 \mathrm{mg} / \mathrm{L}$, which corresponded to the concentrations observed in Lake Geneva water column (Zahner 1984). In pore waters, $\mathrm{SO}_{4}^{-2}$ concentrations were much less and varied between not detectable to $5.6 \mathrm{mg} / \mathrm{L}$. A gradual decrease in concentration between the upper layer $(0-1.5 \mathrm{~cm})$ and the deepest layer was observed. Although layers $0-1.5 \mathrm{~cm}$ were more concentrated in $\mathrm{SO}_{4}^{-2}$ than deeper layers, they were considered as anoxic since these

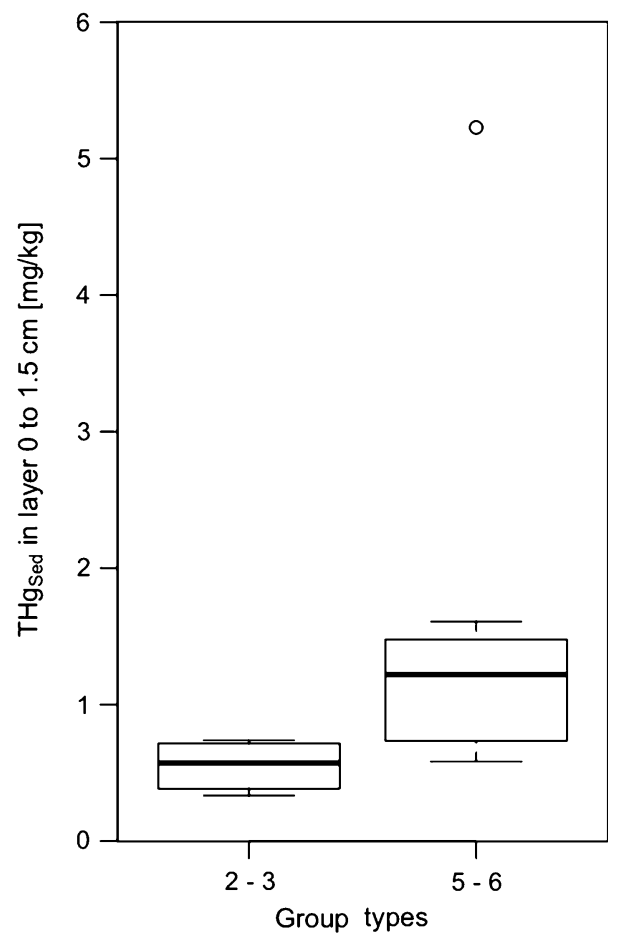

Fig. 3 Concentration ranges of $\mathrm{THg}$ in surface sediments by sediment types (all cores included). The thick line inside the box is the median, the box indicates the upper and lower quartiles, the dashed whisker lines give the range of extreme values to a maximum of 1.5 times the interquartile range. Outliers are indicated with circles concentrations were approximately ten times lower than those recorded in the overlying waters. Additionally, dissolved Fe concentrations (Table 2) corroborated the sulphate results with generally low concentrations (between 7 and $21 \mu \mathrm{g} / \mathrm{L}$ ) in overlying (oxygenated) waters and increased Fe contents with depth in anoxic pore waters (between 26 and 6,990 $\mu \mathrm{g} / \mathrm{L}$ ).

Based on sulphate and Fe measurements, surface layers of all sediment cores showed anoxic conditions. Nevertheless, a brownish surface layer was observed. This colour layer reflects the presence of iron oxides and characterizes sediment of types 2 and 3 (core \#11 and \#9, respectively). Reduced dissolved Fe likely reaches the surface of the sediments and in contact with the oxygenated overlying water might be oxidized. A thin layer of iron (few $\mathrm{mm}$ ) oxides would explain the brownish colour.

\section{$\mathrm{THg}_{\text {sed }}$ : an indicator of the contamination from the WWTP}

$\mathrm{THg}_{\text {sed }}$ concentrations in the 14 sediment cores ranged between 0.32 and $10 \mathrm{mg} / \mathrm{kg}$ (Table 2). The highest $\mathrm{THg}_{\text {sed }}$ concentrations were found in sediment core \#7 (Fig. 1). The maximum value of $\mathrm{THg}$ was about 330 times higher than the natural background level of Lake Geneva $(0.03 \mathrm{mg} / \mathrm{kg}$, Vernet and Viel 1984). $\mathrm{THg}_{\text {sed }}$ concentrations in this sediment core increased with depth (Table 2). This sediment core was also found to be highly concentrated in particulate $\mathrm{Cd}, \mathrm{Pb}$ and $\mathrm{Cu}$ (Masson and Tercier-Waeber 2013, this issue); and to be significantly different in terms of abundance and type of bacteria (Sauvain et al. 2013, this issue). The heterogeneous partition of contaminants in Vidy Bay sediments might result from the wandering of the plume released by the WWTP outlet and subsequent settling of contaminated particles. Although $\mathrm{THg}_{\text {sed }}$ concentrations in core \#2 were lower than those found in core \#7, they were also relatively high in the third layer $(4.4 \mathrm{mg} / \mathrm{kg}$, Table 2$)$. Due to these high values, cores \#2 and \#7 were considered as outliers and not taken into account in further statistical calculations. The dispersion of $\mathrm{THg}_{\text {sed }}$ in the upper layer $(0-1.5 \mathrm{~cm})$ is shown in Fig. 3. Most concentrations measured in the Bay exceeded the Threshold Effect Concentration (TEC) of $0.18 \mathrm{mg} / \mathrm{kg}$ (MacDonald et al. 2000). Additionally, nine of them exceeded, or were at the limit of, the Probable Effect Concentration (PEC) of $1.06 \mathrm{mg} / \mathrm{kg}$. These THg concentrations in Vidy Bay sediments correspond to those reported by Pote et al. (2008). No significant correlation was found between sediment type and the $\mathrm{Hg}$ concentration in the sediments. Nevertheless, the range of $\mathrm{THg}_{\text {sed }}$ concentrations in sediment cores grouped, considering the distance to the WWTP effluent (Fig. 3) showed that type 2-3 (distant to the WWTP effluent) presented lower THg concentrations than type 5-6 (closest to the WWTP effluent). 


\section{$\mathrm{Hg}$ speciation in pore water}

Pore water in core \#7 was found to be highly concentrated in $\mathrm{THg}_{\mathrm{PW}}$ (from 298 to $728 \mathrm{ng} / \mathrm{L}$ ), followed by core \#2 (from 3.5 to $81 \mathrm{ng} / \mathrm{L}$ ). In the other sediment cores, $\mathrm{THg}_{\mathrm{PW}}$ concentrations were lower and ranged between 1.3 and $46.7 \mathrm{ng} / \mathrm{L}$ (Table 2). The $\mathrm{THg}$ partition coefficient, $\log K_{\mathrm{d}}$ (in $\mathrm{L} / \mathrm{kg}$ ), is defined in this study as the ratio between $\mathrm{THg}$ concentrations measured in sediment $\left(\mathrm{THg}_{\text {sed }}\right)$ and in pore water $\left(\mathrm{THg}_{\mathrm{PW}}\right)$ (Turner et al. 2004). The $\log K_{\mathrm{d}}$ values ranged between 3.6 and 5.8. Similar results have been found in Lake Superior and Lake Michigan sediments $\left(\log K_{\mathrm{d}}=4.8 \pm 0.1\right.$ and $\log K_{\mathrm{d}}=5.7$, respectively; Rolfhus et al. 2003; Hurley et al. 1996). The highest $\mathrm{MMHg}_{\mathrm{PW}}$ concentrations have been found in core \#7, ranging between 9 and $22 \mathrm{ng} / \mathrm{L}$. These concentrations were high as compared to the other 13 sediment cores; $\mathrm{MMHg}_{\mathrm{PW}}$ concentrations ranged from 0.32 to $11.1 \mathrm{ng} / \mathrm{L}$. The average $\mathrm{MMHg}_{\mathrm{PW}}$ concentration in all sediments cores, except core \#7, was $4.5 \pm 4.1 \mathrm{ng} / \mathrm{L}$ in the $0-1.5 \mathrm{~cm}$ layer, $2.6 \pm 2.1 \mathrm{ng} / \mathrm{L}$ in the $1.5-3 \mathrm{~cm}$ layer and $7.9 \pm 4.0 \mathrm{ng} / \mathrm{L}$ in the $3-6 \mathrm{~cm}$ layer.

The $\mathrm{MMHg}_{\mathrm{PW}} / \mathrm{THg}_{\mathrm{PW}}$ ratio was found to be depth dependant and was $0.44 \pm 0.25$ in the $0-1.5 \mathrm{~cm}$ layer. This result is similar to that found in other contaminated lacustrine bays, such as Lavaca Bay (Texas) with a $\mathrm{MMHg}_{\mathrm{PW}} / \mathrm{THg}_{\mathrm{PW}}$ ratio of $0.41 \pm 0.33$ (Bloom et al. 1999). In other areas affected by atmospheric $\mathrm{Hg}$ deposition, as in small lakes in
Ontario, Canada, $\mathrm{MMHg}_{\mathrm{PW}} / \mathrm{THg}_{\mathrm{PW}}$ ratio ranged between 0.01 and 0.76 (He et al. 2007). A large proportion of the $\mathrm{MMHg}$ found in Vidy Bay decreased with sediment depth, with $22 \pm 14 \%$ in the $1.5-3 \mathrm{~cm}$ layer and $13 \pm 13 \%$ in the 3-6 cm layer.

The percentage of $\mathrm{MMHg}$ has often been used as a proxy of $\mathrm{Hg}$ methylation activity in sediments (cf. Drott et al. 2008). In the present study, since the $\mathrm{MMHg}_{\mathrm{PW}} /$ $\mathrm{THg}_{\mathrm{PW}}$ ratio was generally higher in the $0-1.5 \mathrm{~cm}$ layer than in deeper layers, the main production of MMHg likely occurs in the surface of sediments. Sulphate (up to $5 \mathrm{mg} / \mathrm{L}$ ) and iron concentrations (Table 2) measured in sediment pore water of Vidy Bay indicates the availability of acceptor electron to the main $\mathrm{Hg}$ methylators, the sulphatereducing and iron-reducing bacteria.

\section{Hg speciation in overlying waters}

$\mathrm{THg}$ concentrations in overlying waters for filtered $(3.0 \pm 0.1 \mathrm{ng} / \mathrm{L})$ and non-filtered overlying water (222 $\pm 17 \mathrm{ng} / \mathrm{L})$ in core \#7 followed the same trend as the parameters measured in the pore water. In core \#2, only the non-filtered overlying water is high in $\mathrm{THg}_{\mathrm{OW}}$ at $55 \pm 2 \mathrm{ng} / \mathrm{L}$. Without taking these outliers into account, $\mathrm{THg}_{\mathrm{O}}$ concentration ranged between 0.40 and $0.92 \mathrm{ng} / \mathrm{L}$ in filtered overlying water; and between 1.48 and $37 \mathrm{ng} / \mathrm{L}$ in non-filtered overlying water.

Table 3 Correlation $p$ values between the measured parameters (in sediments, pore water, and the overlying water) with distance to the WWTP outlet

\begin{tabular}{|c|c|c|c|c|c|}
\hline \multirow{2}{*}{$\begin{array}{l}\text { Parameters in } \\
\text { sediments }\end{array}$} & \multicolumn{2}{|c|}{ Spearman $p$ values } & \multirow{2}{*}{$\begin{array}{l}\text { Parameters in overlying } \\
\text { waters }\end{array}$} & \multicolumn{2}{|c|}{ Spearman $p$ values } \\
\hline & $\begin{array}{l}\text { Layer } \\
0-1.5 \mathrm{~cm}\end{array}$ & $\begin{array}{l}\text { All layers } \\
\text { combined }\end{array}$ & & $\begin{array}{l}\text { Overlying water } \\
\text { non filtered }\end{array}$ & $\begin{array}{l}\text { Overlying water } \\
\text { filtered }\end{array}$ \\
\hline $\mathrm{THg}_{\text {sed }}$ & $0.01 *$ & $0.01 *$ & & & \\
\hline $\mathrm{OM}$ & $0.04 *$ & $0.01 *$ & & & \\
\hline $\mathrm{MMHg}_{\mathrm{PW}}$ & 0.12 & 0.93 & $\mathrm{MMHg}_{\mathrm{OW}}$ & $0.01 *$ & 0.08 \\
\hline $\mathrm{THg}_{\mathrm{PW}}$ & $0.02 *$ & $0.01 *$ & $\mathrm{THg}_{\mathrm{OW}}$ & 0.27 & $0.01 *$ \\
\hline $\mathrm{MMHg}_{\mathrm{PW}} / \mathrm{THg}_{\mathrm{PW}}$ & 0.49 & 0.12 & $\mathrm{MMHg}_{\mathrm{OW}} / \mathrm{THg}_{\mathrm{OW}}$ & 0.59 & 0.64 \\
\hline $\log K_{\mathrm{d}} \mathrm{THg}$ & 0.67 & 0.35 & & & \\
\hline
\end{tabular}

* Indicates a $p<0.05$

Table 4 Independence Mann-Whitney-Wilcoxon test for non-distance correlated variables (Table 3) and the groups of sediment type, $p$ value threshold $=0.05$

\begin{tabular}{|c|c|c|c|c|c|}
\hline \multirow{2}{*}{$\begin{array}{l}\text { Parameters in } \\
\text { sediments }\end{array}$} & \multicolumn{2}{|c|}{ Mann-Whitney-Wilcoxon $p$ values } & \multirow{2}{*}{$\begin{array}{l}\text { Parameters in overlying } \\
\text { waters }\end{array}$} & \multicolumn{2}{|c|}{ Mann-Whitney-Wilcoxon $p$ values } \\
\hline & $\begin{array}{l}\text { Layer } \\
0-1.5 \mathrm{~cm}\end{array}$ & $\begin{array}{l}\text { All layers } \\
\text { combined }\end{array}$ & & $\begin{array}{l}\text { Overlying water } \\
\text { non filtered }\end{array}$ & $\begin{array}{l}\text { Overlying water } \\
\text { filtered }\end{array}$ \\
\hline $\mathrm{MMHg}_{\mathrm{PW}}$ & 0.73 & 0.97 & $\mathrm{MMHg}_{\mathrm{OW}}$ & & 0.06 \\
\hline $\log K_{\mathrm{d}} \mathrm{THg}$ & 1.00 & 0.95 & THgow & 0.86 & \\
\hline $\mathrm{MMHg}_{\mathrm{PW}} / \mathrm{THg}_{\mathrm{PW}}$ & 0.37 & 0.22 & $\mathrm{MMHg}$ ow $/ \mathrm{THg}_{\text {ow }}$ & 0.60 & 0.33 \\
\hline
\end{tabular}


The highest MMHgow concentrations were found in core \#7 in filtered and non-filtered overlying waters $(0.5 \pm 0.1$ and $3.7 \pm 0.2 \mathrm{ng} / \mathrm{L}$, respectively) as compared to the other 13 sediment cores, where $\mathrm{MMHg}_{\mathrm{O}}$ concentrations ranged between 0.03 and $0.20 \mathrm{ng} / \mathrm{L}$ for filtered overlying waters, and between 0.14 and $1.7 \mathrm{ng} / \mathrm{L}$ for nonfiltered overlying waters. In any case, MMHg concentrations found in Vidy Bay lake bottom waters exceed the value of $0.05 \mathrm{ng} / \mathrm{L}$ found in the centre of Lake Geneva (Bravo 2010).

MMHg concentrations measured in overlying waters were between 10 and 100 times lower than those measured in pore waters, indicating a probable diffusion of $\mathrm{MMHg}$ from the sediments to the water column, and showing that methylation takes place preferentially in the surface sediments as observed in many studies (cf. Ullrich et al. 2001). However, no correlation was found between $\mathrm{MMHg}_{\mathrm{PW}}$ (layer 0-1.5 cm) and $\mathrm{MMHg}_{\mathrm{OW}}\left(r_{\mathrm{s}}=0.042\right)$.

\section{Influence of sediment types on $\mathrm{Hg}$ forms}

For layer $0-1.5 \mathrm{~cm}$ and all layers combined, a Spearman test showed a significant negative correlation between distance to the WWTP outlet and the following parameters: $\mathrm{THg}_{\text {Sed }}, \mathrm{THg}_{\mathrm{PW}}$, filtered $\mathrm{THg}_{\mathrm{OW}}$ and non-filtered $\mathrm{MMHg}_{\mathrm{OW}}$ concentrations ( $p$ values $<0.05$; Table 3 ).

Because the sediment types were also dependant on distance from the WWTP outlet (Fig. 1), it was not possible to evaluate whether there was a statistically significant difference of these parameters between sediment types.

On the other hand, $\log K_{\mathrm{d}}, \mathrm{MMHg}_{\mathrm{PW}}, \mathrm{MMHg}_{\mathrm{PW}} / \mathrm{THg}_{\mathrm{PW}}$ ratios, non-filtered $\mathrm{THg}_{\mathrm{OW}}$ and filtered $\mathrm{MMHg}_{\mathrm{OW}}$ concentrations were not correlated to distance from the WWTP outlet ( $p$ values $>0.05$; Table 3 ). Therefore a MannWhitney-Wilcoxon test was performed to assess the differences between sediment types for these parameters. All $p$ values were found to be $>0.05$ (Table 4), which suggests that there was no statistical difference between sediment type and $\log K_{\mathrm{d}}, \mathrm{MMHg}_{\mathrm{PW}}, \mathrm{MMHg}_{\mathrm{PW}} / \mathrm{THg}_{\mathrm{PW}}$ ratio, nonfiltered $\mathrm{THg}_{\mathrm{OW}}$ and filtered $\mathrm{MMHg}_{\mathrm{OW}}$ concentrations. Therefore, at the studied scale, it appeared that the strong differences in sediment surfaces were essentially due to redox variations at the sediment surface and the presence or absence of a bacterial mat (Sauvain et al. 2013, this issue). These differences seemed to have no direct effect on mercury transformation processes in the sediment. The survey performed in the present study could not assess the impact of the noticeably altered sediments (sediment type 5: $0.25 \mathrm{~km}^{2}$, in the vicinity of the WWTP) on mercury fate. However, a large variation in the concentration of mercury forms, uncorrelated to distance to the main source, still were observed. For instance, $\mathrm{MMHg}_{\mathrm{PW}}$ concentrations ranged between 0.26 and $27.2 \mathrm{ng} / \mathrm{L}$ in core samples. These variations should be related to local heterogeneities of biogeochemical processes at the scale of centimetres to metres.

\section{Summary}

$\mathrm{THg}_{\mathrm{PW}}$ concentrations were found to be high in the whole Bay with concentrations increasing as sampling sites approached the main source. This correlation between distance and $\mathrm{THg}_{\mathrm{PW}}$ concentration confirms the WWTP as a source of $\mathrm{Hg}$ contamination within the Bay. $\mathrm{MMHg}_{\mathrm{PW}}$ concentrations and their fraction on $\mathrm{THg}_{\mathrm{PW}}$ were not directly influenced by the WWTP effluent; this indicated that biogeochemical processes, not visually apparent from the sediment types, dominated $\mathrm{MMHg}$ formation in pore waters. $\mathrm{MMHg}_{\mathrm{PW}}$ concentrations and the $\mathrm{MMHg}_{\mathrm{PW}} / \mathrm{THg}_{\mathrm{PW}}$ ratios were higher in the top sediment layer, indicating a higher methylation rate in these sediments. The integration of physicochemical parameters and bacteria biodiversity analysis on these superficial sediments would be of great interest to understand the source of increased $\mathrm{MMHg}_{\mathrm{PW}}$, as compared to sediment depth, to sediment type, and to other aquatic environments.

Acknowledgments This publication is part of the international, interdisciplinary research project ELEMO (http://www.elemo.ch) to investigate the deep-waters of Lake Geneva using two Russian MIR submarines. Funding for this study was provided by the Fondation pour l'Etude des Eaux du Léman (FEEL). Additional funding for the work described in this paper was provided by Swiss National Science Foundation SNSF PDFMP2 123034 and 123048 (LÉMAN-21). We are grateful for the support. We thank the Russian MIR crew members (www.elemo.ch/mir-team) for their excellent performance and the SAGRAVE team who provided and operated the platform from which the dives were carried out. We also thank Ulrich Lemmin and JeanDenis Bourquin for project coordination. The service of Mikhail Kranoperov (Russian Honorary Consulate) as liaison is greatly appreciated. Philippe Arpagaus piloted the "La Licorne" scientific vessel for supplementary sampling. Marylou Tercier-Waeber for helping in supplementary sampling and writing advises. The manuscript greatly benefits from comments of two anonymous reviewers and Alfred Wüest.

\section{References}

Akhtman Y, Martelletti L, Greanjean O, Lemmin U (2012) Collaborative Web-GIS platform for systematic exploration of Lake Geneva. In: Proceedings of the XXII Congress of the International Society for Photogrammetry and Remote Sensing, vol. XXXIX-B4, num. IV/1, p. 1-6, 25 August-1 September 2012, Melbourne, Australia

Bale AE (2000) Modeling aquatic mercury fate in Clear Lake. Calif J Environ Eng 126:153-163

Blank N, Hudson AG, Vonlanthen P, Seehausen O, Hammerschmidt CR, Senn DB (2013) Speciation leads to divergent methylmercury accumulation in sympatric whitefish. Aquat Sci 75:261-273 
Blasco J, Saenz V, Gomez-Parra A (2000) Heavy metal fluxes at the sediment-water interface of three coastal ecosystems from southwest of the Iberian Peninsula. Sci Total Environ 247:189-199

Bloom NS, Gill GA, Cappellino S, Dobbs C, Mcshea L, Driscoll C, Mason R, Rudd J (1999) Speciation and cycling of mercury in Lavaca Bay, Texas, sediments. Environ Sci Technol 33:7-13

Bravo AG (2010) Mercury methylation and trophic transfer in contaminated freshwater systems. Université de Geneve, Dissertation

Bravo AG, Bouchet S, Amouroux D, Pote J, Dominik J (2011) Distribution of mercury and organic matter in particle-size classes in sediments contaminated by a waste water treatment plant: Vidy Bay, Lake Geneva, Switzerland. J Environ Monitor 13:974-982

Clarkson TW (1993) Mercury-major issues in environmental-health. Environ Health Perspect 100:31-38

Compeau GC, Bartha R (1985) Sulfate-reducing bacteria-principal methylators of mercury in anoxic estuarine sediment. Appl Environ Microbiol 50:498-502

Cossa D, Harmelin-Vivien M, Mellon-Duval C, Loizeau V, Averty B, Crochet S, Chou L, Cadiou JF (2012) Influences of bioavailability, trophic position, and growth on methylmercury in hakes (Merluccius merluccius) from northwestern Mediterranean and northeastern Atlantic. Environ Sci Technol 46:4885-4893

DeLaune RD, Jugsujinda A, Devai I, Patrick WH (2004) Relationship of sediment redox conditions to methyl mercury in surface sediment of Louisiana Lakes. J Environ Sci Health A Tox Hazard Subst Environ Eng 39:1925-1933

Dominik J, Loizeau JL, Span D (1992) Radioisotopic evidence of perturbations of recent sedimentary record in lakes: a word of caution for climate studies. Clim Dynam 6:145-152

Drott A, Lambertsson L, Björn E, Skyllberg U (2008) Do potential methylation rates reflect accumulated methyl mercury in contaminated sediments? Environ Sci Technol 42:153-158

Fitzgerald WF, Mason RP, Vandal GM (1991) Atmospheric cycling and air-water exchange of mercury over midcontinental lacustrine regions. Water Air Soil Poll 56:745-767

Fleming EJ, Mack EE, Green PG, Nelson DC (2006) Mercury methylation from unexpected sources: molybdate-inhibited freshwater sediments and an iron-reducing bacterium. Appl Environ Microb 72:457-464

Gilmour C, Henry E (1991) Mercury methylation in aquatic systems affected by acid deposition. Environ Pollut 71:131-169

Gilmour C, Henry E, Mitchell R (1992) Sulfate stimulation of mercury methylation in freshwater sediments. Environ Sci Technol 26:2281-2287

Girardclos S, Hilbe M, Corella JP, Loizeau JL, Kremer K, DelSontro T, Arantegui A, Moscariello A, Arlaud F, Akhtman Y, Anselmetti F, Lemmin U (2012) Searching the Rhone delta channel in Lake Geneva since François-Alphonse Forel. Arch Sci 65:103-118

Hamelin S, Amyot M, Barkay T, Wang YP, Planas D (2011) Methanogens: principal methylators of mercury in Lake Periphyton. Environ Sci Technol 45:7693-7700

Harada M (1995) Minamata disease-methylmercury poisoning in Japan caused by environmental-pollution. Crit Rev Toxicol 25:1-24

He TR, Lu J, Yang F, Feng XB (2007) Horizontal and vertical variability of mercury species in pore water and sediments in small lakes in Ontario. Sci Total Environ 386:53-64

Hurley JP, Shafer MM, Cowell SE, Overdier JT, Hughes PE, Armstrong DE (1996) Trace metal assessment of Lake Michigan tributaries using low-level techniques. Environ Sci Technol 30:2093-2098

Kerin EJ, Gilmour C, Roden E, Suzuki MT, Coates JD, Mason RP (2006) Mercury methylation by dissimilatory iron-reducing bacteria. Appl Environ Microb 72:7919-7921
Langer CS, Fitzgerald WF, Visscher PT, Vandal GM (2001) Biogeochemical cycling of methylmercury at Barn Island Salt Marsh, Stonington, CT, USA. Wetl Ecol Manag 9:295-310

Loizeau JL, Arbouille D, Santiago S, Vernet JP (1994) Evaluation of a wide-range laser diffraction grain-size analyzer for use with sediments. Sedimentology 41:353-361

Loizeau JL, Pardos M, Monna F, Peytremann C, Haller L, Dominik J (2004) The impact of a sewage treatment plant's effluent on sediment quality in a small bay in Lake Geneva (SwitzerlandFrance). Part 2. Temporal evolution of heavy metals. Lakes Reserv Res Manag 9:53-63

MacDonald DD, Ingersoll CG, Berger TA (2000) Development and evaluation of consensus-based sediment quality guidelines for freshwater ecosystems. Arch Environ Con Tox 39:20-31

Mason RP, Reinfelder JR, Morel FMM (1995) Bioaccumulation of mercury and methylmercury. Water Air Soil Poll 80:915-921

Masson M, Tercier-Waeber ML (2013) Trace metal speciation at the sediment-water interface of the Vidy Bay: Influence of contrasting sediment characteristics. Aquat Sci (this issue)

Monperrus M, Tessier E, Veschambre S, Amouroux D, Donard O (2005) Simultaneous speciation of mercury and butyltin compounds in natural waters and snow by propylation and speciesspecific isotope dilution mass spectrometry analysis. Anal Bioanal Chem 381:854-862

Pak K, Bartha R (1998) Mercury methylation and demethylation in anoxic lake sediments and by strictly anaerobic bacteria. Appl Environ Microb 64:1013-1017

Pardos M, Benninghoff C, De Alencastro LF, Wildi W (2004) The impact of a sewage treatment plant's effluent on sediment quality in a small bay in Lake Geneva (Switzerland-France). Part 1: spatial distribution of contaminants and the potential for biological impacts. Lakes Reserv Res Manage 9:41-52

Parks JM, Johs A, Podar M, Bridou R, Hurt RA, Smith SD, Tomanicek SJ, Qian Y, Brown SD, Brandt CC, Palumbo AV, Smith JC, Wall JD, Elias DA, Liang L (2013) The genetic basis for bacterial mercury methylation. Science 339:1332-1335

Pote J, Haller L, Loizeau JL, Bravo AG, Sastre V, Wildi W (2008) Effects of a sewage treatment plant outlet pipe extension on the distribution of contaminants in the sediments of the Bay of Vidy, Lake Geneva, Switzerland. Bioresour Technol 99:7122-7131

Rolfhus KR, Sakamoto HE, Cleckner LB, Stoor RW, Babiarz CL, Back RC, Manolopoulos H, Hurley JP (2003) Distribution and fluxes of total and methylmercury in Lake Superior. Environ Sci Technol 37:865-872

Roos-Barraclough F, Givelet N, Martinez-Cortizas A, Goodsite ME, Biester H, Shotyk W (2002) An analytical protocol for the determination of total mercury concentrations in solid peat samples. Sci Total Environ 292:129-139

Sauvain L, Bueche M, Junier T, Masson M, Wunderlin T, KohlerMilleret R, Gascon Diez E, Loizeau JL, Tercier-Waeber ML, Junier P (2013) Bacterial communities in trace metal contaminated lake sediments are dominated by endospore-forming bacteria. Aquat Sci (this issue)

Schafer J, Blanc G, Audry S, Cossa D, Bossy C (2006) Mercury in the Lot-Garonne River system (France): sources, fluxes and anthropogenic component. Appl Geochem 21:515-527

Scheulhammer AM, Meyer MW, Sandheinrich MB, Murray MW (2007) Effects of environmental methylmercury on the health of wild birds, mammals, and fish. Ambio 36:12-18

Siegel S (1956) Nonparametric statistics for the behavioral sciences. Kosaido Printing Co. Ltd, Tokyo

Sturm M, Zwissig A, Piccard J (1984) Bio-erosive humpackstructures - an example of sediment/water interface alteration in Lake Geneva. In: proceeding of third Inter Symposium Interaction between Sediments and Water, CEP Consultants: 126 
Száková J, Kolihová D, Miholová D, Mader P (2004) Single-purpose atomic absorption spectrometer AMA-254 for mercury determination and its performance in analysis of agricultural and environmental materials. Chem Pap 58:311-315

Turner A, Millward GE, Le Roux SM (2004) Significance of oxides and particulate organic matter in controlling trace metal partitioning in a contaminated estuary. Mar Chem 88:179-192

Ullrich SM, Tanton TW, Abdrashitova SA (2001) Mercury in the aquatic environment: a review of factors affecting methylation. Crit Rev Env Sci Tec 31:241-293

Vernet JP (1966) Prise de vue sous-lacustres dans le Léman lors de plongées du mésoscaphe “Auguste-Picard”. Bull Soc Vaudoise Sci Nat 69:287-292

Vernet JP, Viel M (1984) Métaux lourds dans les sédiments lacustres. In: Commission Internationale pour la Protection des Eaux du
Léman contre la Pollution (ed) Synthèse des travaux 1957-1982, Lausanne, pp 227-238

Watras CJ, Bloom NS (1992) Mercury and methylmercury in individual zooplankton-implications for bioaccumulation. Limnol Oceanogr 37:1313-1318

WHO/IPCS (1990) Methylmercury. Geneva, World Health Organization, International Programme on Chemical Safety. Environ health criteria $101 \mathrm{WHO}$ library cataloguing in publication data

Wüest A, Anselmetti FS, Arey JS, Ibelings BW, Loizeau JL, Vennemann T, Lemmin U (2013) Into the abyss of Lake Geneva-interdisciplinary field investigations using the MIR submersibles. Aquat Sci (this issue)

Zahner P (1984) Sulfates. In: Commission Internationale pour la Protection des Eaux du Léman contre la Pollution (ed) Synthèse des travaux 1957-1982, Lausanne, pp 193-198 